\title{
Securing biodiversity and ecosystem services in Africa: Notes from the 2015 Satoyama Initiative Regional Workshop in Accra, Ghana
}

\begin{tabular}{|c|c|}
\hline \multicolumn{2}{|c|}{$\begin{array}{l}\text { Authors: } \\
\text { Alfred Oteng-Yeboah }{ }^{1} \\
\text { William Dunbar } \\
\text { Yaw A. Boafo } \\
\text { Kaoru Ichikawa }{ }^{2}\end{array}$} \\
\hline $\begin{array}{l}\text { Affiliations: } \\
{ }^{1} \text { Department } \\
\text { University of } C\end{array}$ & $\begin{array}{l}\text { f Botany, } \\
\text { hana, Ghana }\end{array}$ \\
\hline \multicolumn{2}{|c|}{$\begin{array}{l}{ }^{2} \text { International Partnership for } \\
\text { the Satoyama Initiative, } \\
\text { United Nations University } \\
\text { Institute for the Advanced } \\
\text { Study of Sustainability, Japan }\end{array}$} \\
\hline \multicolumn{2}{|c|}{$\begin{array}{l}{ }^{3} \text { The Integrated Research } \\
\text { System for Sustainability } \\
\text { Science, The University of } \\
\text { Tokyo Institute for Advanced } \\
\text { Study, Japan }\end{array}$} \\
\hline \multicolumn{2}{|c|}{$\begin{array}{l}\text { Corresponding author: } \\
\text { Yaw Boafo, } \\
\text { boafo@ir3s.u-tokyo.ac.jp }\end{array}$} \\
\hline \multicolumn{2}{|c|}{$\begin{array}{l}\text { Dates: } \\
\text { Received: } 30 \text { Oct. } 2015 \\
\text { Accepted: } 23 \text { Mar. } 2016 \\
\text { Published: } 31 \text { May } 2016\end{array}$} \\
\hline \multicolumn{2}{|c|}{$\begin{array}{l}\text { How to cite this article: } \\
\text { Oteng-Yeboah, A., Dunbar, } \\
\text { W., Boafo, Y.A. \& Ichikawa, K., } \\
2016 \text {, 'Securing biodiversity } \\
\text { and ecosystem services in } \\
\text { Africa: Notes from the } 2015 \\
\text { Satoyama Initiative Regional } \\
\text { Workshop in Accra, Ghana', } \\
\text { Bothalia } 46(1) \text {, a2030. http:// } \\
\text { dx.doi.org/10.4102/abc. } \\
\text { v46i1.2030 }\end{array}$} \\
\hline \multicolumn{2}{|c|}{$\begin{array}{l}\text { Copyright: } \\
\text { (C) 2016. The Authors. } \\
\text { Licensee: AOSIS. This work } \\
\text { is licensed under the } \\
\text { Creative Commons } \\
\text { Attribution License. }\end{array}$} \\
\hline \multicolumn{2}{|l|}{ Read online: } \\
\hline 口pista & $\begin{array}{l}\text { Scan this QR } \\
\text { code with your } \\
\text { smart phone or } \\
\text { mobile device } \\
\text { to read online. }\end{array}$ \\
\hline
\end{tabular}

The first Satoyama Initiative Regional Workshop in Africa was held in Accra, Ghana, from 10 to 12 August 2015. The objective of the workshop was to contribute to the sustainable development agenda in the region within the scope of biodiversity and ecosystem functioning by strengthening the knowledge base related to the Satoyama Initiative, a global effort 'to realize societies in harmony with nature' through the revitalisation and sustainable development of 'socio-ecological production landscapes and seascapes'. This short report summarises some of the main points arising from the workshop.

\section{Introduction}

The first Satoyama Initiative Regional Workshop in Africa was held in Accra, Ghana, from 10 to 12 August 2015. The Satoyama Initiative is a global effort initiated through the collaborative efforts of the Ministry of the Environment of Japan and the United Nations University Institute for the Advanced Study of Sustainability based in Tokyo, Japan. The term satoyama is a Japanese word denoting a model of harmonious existence between humans and nature in a landscape, and the Satoyama Initiative aims to globally share and highlight the concept that humans and nature can have mutually beneficial relationships through sustainable resource management. Such relationships are seen in many management practices around the world, but are often not recognised by decision-makers. For this reason, an objective of the initiative is to promote the revitalisation and sustainable management of 'socio-ecological production landscapes and seascapes' (SEPLS) (Gu \& Subramanian 2014; Satoyama Initiative 2013), with the ultimate goal 'to realize societies in harmony with nature' (Satoyama Initiative 2015).

\section{Workshop programme}

The workshop was organised by the Secretariat of the International Partnership for the Satoyama Initiative (IPSI) and hosted by the United Nations University Institute for the Advanced Study of Sustainability in collaboration with partners from Ghana. The workshop brought together more than 75 participants from 20 countries, including practitioners, scientists, representatives from research organisations and policymakers. The objectives were to create a shared understanding of issues related to SEPLS, promote more effective communication among stakeholders and identify effective ways for the Satoyama Initiative to contribute to sustainable development in Africa. The programme included presentations by stakeholders and experts from 13 African countries, group discussions and plenary sessions, specifically aimed at addressing two principal questions:

- What are the status of, trends in, and threats facing SEPLS in Africa?

- What should be done for the revitalisation, conservation and sustainable management of SEPLS in Africa?

Presentations and discussions took place in plenary and in four working groups covering a diversity of ecosystems on the African continent - forest, dryland, aquatic and agricultural. In the forest working group, the main threats and challenges identified were bushfires, climate change, over-exploitation, loss of traditional norms and taboos, expansion of farmlands, land ownership and conflict of interests; and the opportunities identified were raising public awareness to restore degraded areas, promoting local partnerships, provision of alternative livelihoods and exploration of co-ownership and co-management of forests. The dryland working group identified climate change and variability, water shortage, desertification, transhumance, bushfires, land degradation and fragmentation as major threats; and integrative land and water management techniques, exploring resilient traditional practices, pasture management, involvement of local communities 
in resource management and alternative livelihood strategies as opportunities for ensuring sustainable use of dryland ecosystems. In the aquatic working group, presentations and discussions led to the identification of threats and challenges such as erosion, land-use changes, resettlement conflicts, reduced food production, water flow loss, biodiversity loss and flooding; and opportunities included community empowerment, education, increased policy coherence, integrated coastal zone management and adoption of simple technologies for resource management. The agricultural working group deliberations focused particularly on encroachment, climate change, loss of soil fertility and unsustainable farming practices as threats and capacity development and awareness creation strategies including promotion of organic agriculture, fisheries, soil conservation and restoration, equitable sharing and distribution of incomes and resources as benefits and opportunities.

At the final plenary session, a common theme was the need to avoid reinventing the wheel or creating parallel systems for the sustainable management of biodiversity and ecosystems in Africa as there are existing policies and plans that can serve the purpose. The following recommendations were proposed based on the current situation of SEPLS in Africa:

- Adopting pragmatic and sustainable public-private partnerships towards the operationalisation and implementation of policies and strategies.

- Identifying innovative and effective awareness creation and information dissemination strategies in order to reach a wide audience within and across scales of operation.

- Finding the appropriate balance of traditional and modern technologies as tools for data collection, monitoring and management.

- Educating farmers and other producers in the importance of conservation and sustainable resource management to raise awareness beyond academic and policymaking circles.

- Exploring livelihood diversification and capacity development strategies to help reduce local communities' direct dependence on nature-based resources.

\section{Conclusion}

As a result of the workshop, the IPSI Secretariat has produced an official report for dissemination: http://satoyamainitiative.org/wp/wp-content/uploads/2015/10/20150810-
12-Africa-Regional-Workshop-Report.pdf. A book is also planned, tentatively titled 'Socio-ecological Production Landscapes and Seascapes in Africa', to be similar to the earlier publication, 'SEPLs in Asia'. (http://satoyamainitiative.org/wp/wp-content/uploads/2015/04/SEPL_in_ Asia_report_high_quality.pdf).

Because of the great deal of interest from African organisations, work has begun on an IPSI-based forum at the regional level to promote work towards SEPLS in Africa. The partnership also continues to grow in numbers and influence in the continent, and members' individual and collaborative work will continue to promote the benefits of SEPLS for sustainable development in Africa.

\section{Acknowledgements}

The IPSI Secretariat would like to thank the Government of Ghana through the Ghana National Biodiversity Committee, the Forestry Commission of Ghana and the Ministry of Environment, Science, Technology and Innovation and the Ministry of the Environment of Japan, as well as cooperating local Ghanaian conservation organisations A Rocha Ghana and Conservation Alliance. The authors are also grateful to the various workshop participants, experts and individuals who contributed in diverse ways in ensuring a successful regional workshop.

\section{Competing interests}

The authors declare that they have no financial or personal relationships which may have inappropriately influenced them in writing this article.

\section{Authors' contributions}

A.O-Y. was responsible for coordinating the Satoyama Initiative Regional Workshop in Africa activities from Ghana and also provided supervision in drafting this report. W.D. and K.I. were responsible for organising the workshop as members of the IPSI Secretariat and with Y.A.B. for initial drafting, reviewing literature and revising the manuscript.

\section{References}

Gu, H. \& Subramanian, S.M., 2014, 'Drivers of change in socio-ecological production landscapes: Implications for better management', Ecology and Society 19(1), 41.

Satoyama Initiative, 2013, 'Strategy for the International Partnership for the Satoyama Initiative', viewed February 22 2015, from http://satoyama-initiative.org/wp/wpcontent/uploads/2014/01/IPSI-Strategy.pdf

Satoyama Initiative, 2015, 'Concept', viewed October 26 2015, from http://satoyamainitiative.org/en/about/ 